\title{
Multiple foreign body aspiration: a case report
}

Aspiracja mnogich ciał obcych: opis przypadku

Department of Otorhinolaryngology - Head and Neck Surgery, School of Medical Sciences, Universiti Sains Malaysia Health Campus, 16150 Kota Bharu, Kelantan, Malaysia Correspondence: Dr Norhafiza Mat Lazim - ORL - Head and Neck Surgeon (Clinical Fellowship Head and Neck Surgical Oncology, Antoni Van Leeuwenhoek-Netherlands Cancer Institute); Department of Otorhinolaryngology - Head and Neck Surgery, School of Medical Sciences, Universiti Sains Malaysia Health Campus, 16150 Kota Bharu, Kelantan, Malaysia, tel.: +6097676420, fax: +6097676424, e-mail: norhafiza@usm.my

Abstract Foreign body in the tracheobronchial tree is an emergency commonly affecting the paediatric age group. A delay in diagnosis and removal may cause high morbidity and mortality. We report a case of a 1-year-6-month-old presenting with multiple peanuts aspirated into both lungs, ultimately resulting in death due to cardiopulmonary complications. The aim of the case report is to highlight the importance of thorough history-taking from parents, intraoperative suspicion of more than a single aspirated foreign body, and meticulous measurements taken to minimise extraction time.

Keywords: foreign body, aspiration, child

Streszczenie Ciało obce w drzewie tchawiczo-oskrzelowym jest stanem nagłym, który często występuje w pediatrycznej grupie wiekowej. Opóźnienie w rozpoznaniu i usunięciu ciała obcego może skutkować wysoką chorobowością i śmiertelnością. Przedstawiamy przypadek chłopca w wieku 1 roku i 6 miesięcy, u którego doszło do aspiracji kilku orzeszków ziemnych obustronnie do płuc. Przypadek zakończył się śmiercią dziecka z powodu powikłań sercowo-płucnych. Prezentowany opis przypadku ma na celu zwrócenie uwagi na konieczność zbierania dokładnego wywiadu od rodziców, śródoperacyjnego podejrzenia aspiracji więcej niż jednego ciała obcego oraz oceny warunków anatomicznych i wyboru instrumentacji umożliwiającej maksymalne skrócenie czasu zabiegu.

Słowa kluczowe: ciało obce, aspiracja, dziecko 


\section{INTRODUCTION}

$\mathrm{F}$ oreign body aspiration cases are commonly seen in children less than 3 years old. The child may be asymptomatic at the initial presentation, but the correlation of history taken from the caretaker is important for corroborating a suspicion, and exploration under general anaesthesia is required without further delay ${ }^{(1)}$. Multidisciplinary teamwork involving an anaesthesiologist, paediatric otolaryngologist and general paediatrician is important, as the small paediatric airways share the same route for ventilation and bronchoscopy ${ }^{(1)}$. Death commonly occurs due to asphyxia, depending on the size and location of the foreign body in the airway ${ }^{(2)}$.

\section{CASE REPORT}

A previously well 2-year-old toddler boy was brought to the emergency department with a sudden onset of coughing and choking. Prior to this, the mother saw the child consume a handful of peanuts while playing with his toys at home. He then developed bluish discoloration of the face and vomited multiple small pieces of peanuts, which was followed by rapid and noisy breathing.

Upon arrival in the emergency room, he was restless, with weak crying. The vital signs showed a respiratory rate of 40 per minute and a pulse of 150 per minute, with a blood pressure of $88 / 53$. Saturation under room air was maintained at $99 \%$. Audible inspiratory stridor and deep subcostal recession were noted on inspection. On auscultation, we heard reduced breath sound intensity and generalised rhonchi in both lungs. The boy was nebulised, but still had stridor and subcostal recession. The chest radiograph was suggestive of hyperinflated left lung. No features of foreign body or consolidation were seen (Fig. 1). The radiograph of the neck was normal. Flexible paediatric nasopharyngeal laryngoscopy was done in the resuscitation zone with unremarkable findings. He was immediately brought to the operation theatre. Endotracheal intubation using positive pressure ventilation was given.

Direct laryngoscopy and rigid bronchoscopy were performed. Intraoperatively, multiple pieces of peanuts over the left and

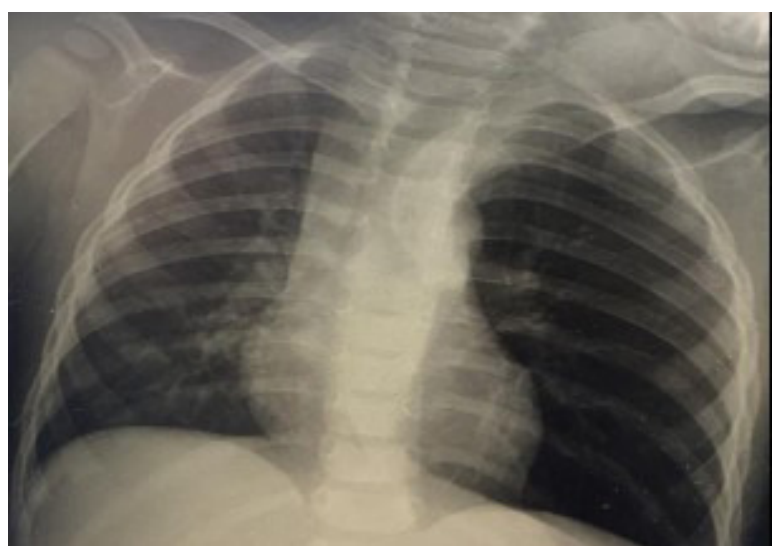

Fig. 1. Chest radiograph showing hyperinflated left lung
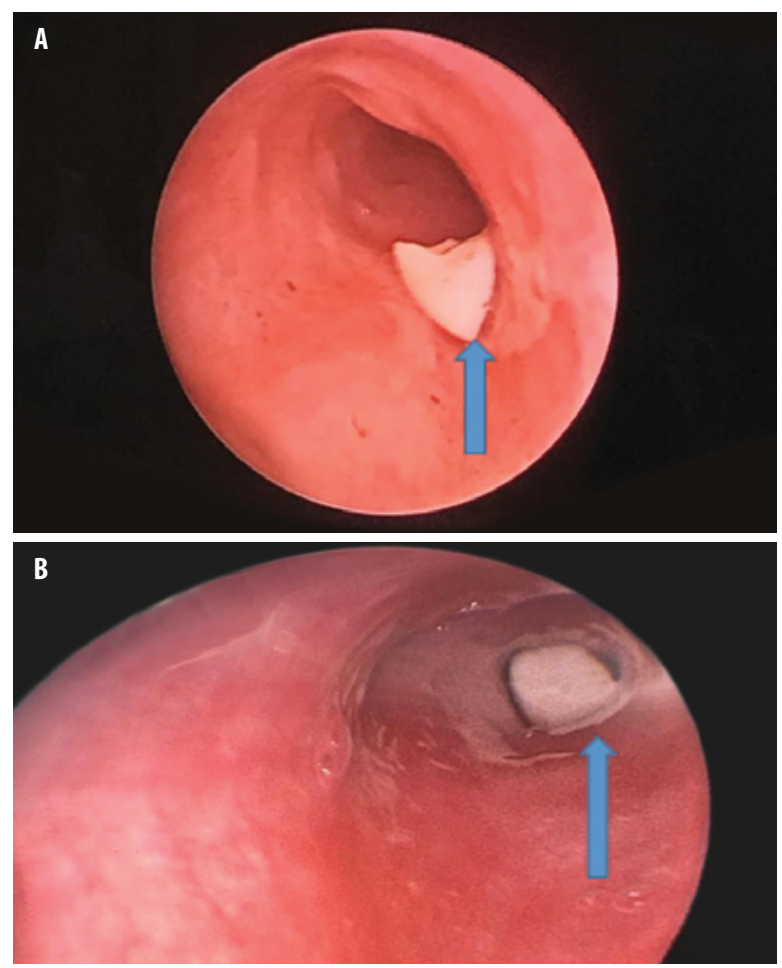

Fig. 2. A peanut (blue arrow) over the right main bronchus (A) and over the left distal main bronchus (B)

right main bronchi were noted (Fig. 2). The removal of the foreign bodies was time-consuming due to their slippery and irregular sizes (Fig. 3). Two episodes of dislodgement into the airway were experienced upon extraction using optical forceps. Five pieces of peanuts managed to be removed from both main bronchi. While removing the sixth or the last piece from the left bronchus, the child had desaturation due to tracheal blockage and we had to push it more distally to allow ventilation of the other lung. We then made multiple attempts at removal using optical forceps, but failed because of its more distal position. Mucosal trauma was noted at the floor of the tracheal wall. Another attempt at removal using dormia basket (DB) forceps was undertaken. However, the patient desaturated, and cardiac monitor showed supraventricular tachycardia. The procedure was abandoned, and the boy was transferred to the surgical intensive care unit (ICU) for stabilisation. His condition remained unstable on triple inotropes complicated by coagulopathy. He underwent multiple cardiopulmonary resuscitation attempts in the ICU, and eventually succumbed to death on day 6 of ICU admission.

\section{DISCUSSION}

Suspected foreign body aspiration in children can be a challenge to diagnose. History can be taken from the child's caretaker or any eye witness, including important chronological events from the period of ingestion and the ensuing respiratory symptoms. The child will appear asymptomatic if the ingested foreign body is small and partially blocking the main bronchus, allowing some ventilation, which 

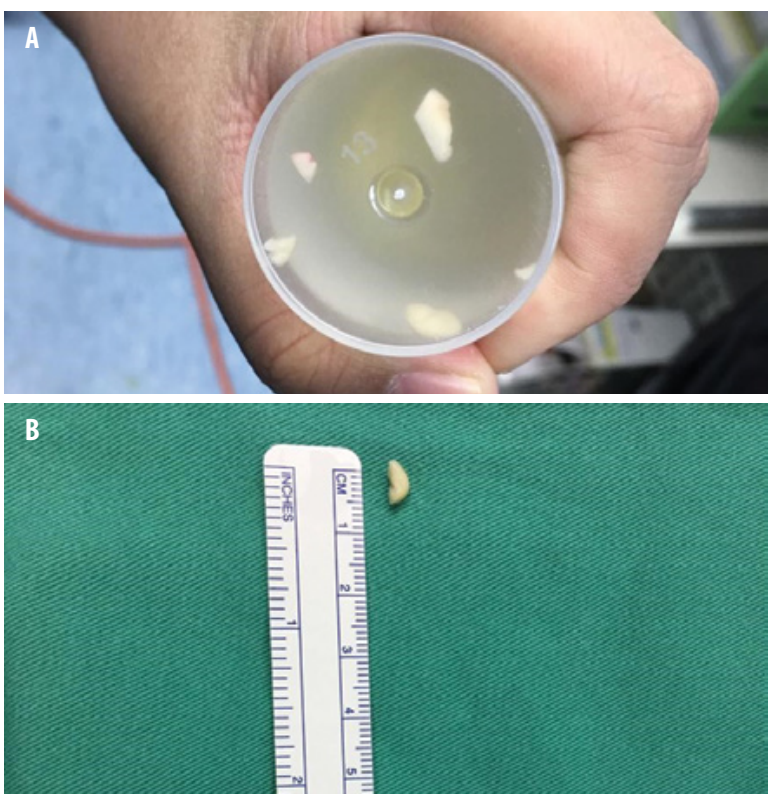

Fig. 3. Five extracted pieces of peanuts (A) with irregular shapes and sizes, each approximately $1 \mathrm{~cm}$ long (B)

leads to a delay in diagnosis ${ }^{(1)}$. The clinician who first evaluates the patient might misinterpret the presenting symptoms and establish a different diagnosis including pneumonia, acute exacerbation of asthma or bronchiolitis ${ }^{(2)}$. The classical penetration syndrome of choking followed by intractable coughing is common in the paediatric age group compared to adults with foreign body aspiration ${ }^{(3)}$. In our case, the child was referred to the otolaryngology team after all the necessary evaluations and an attempt at nebulisation were done. From the given history of suspicious foreign body aspiration, an emergency exploration under general anaesthesia was warranted even before all the evaluations were carried out. Foreign body aspiration is more commonly present in males than in females, with a ratio of $2: 1$. Most foreign bodies are found in the right main stem bronchus in adults due to its more vertical, wider and shorter course. However, the foreign body can be found in both main stem bronchi with the same probability in children under 15 years old due to their similar size and angulation ${ }^{(4)}$. In our case, the child was of male gender, and had multiple pieces of peanuts found in both his main bronchi. Chest radiograph is the most frequently carried out examination in foreign body aspiration cases. It is cheap and easily available in most centres. Nevertheless, it has low sensitivity and specificity in visualising aspirated foreign bodies, and has little benefit in confirming or excluding the diagnosis of foreign body aspiration. Most inhaled foreign bodies are not radiopaque, and hence secondary changes such as hyperinflation, bronchiectasis or lobar collapse may be suggestive ${ }^{(5)}$. Peanuts and other vegetables are radiolucent. In our case, the child's chest radiograph showed hyperinflated left lung fields. Preoperative planning involving the anaesthesiologist, the surgeon and the assistant nurse is important to ensure a patent airway and adequate ventilation which need to be carefully considered, as interruption of airway stability may be necessary during the procedure ${ }^{(6)}$. It is crucial to discuss the options to re-establish the airway before extraction, as the foreign body may cause complete airway obstruction upon removal ${ }^{(6)}$. In our case, endotracheal intubation and positive pressure ventilation were chosen, as the risk of hypoxemia was a concern. The inner diameter of the bronchoscope was too small for a foreign body to pass through along the optical forceps and endoscope, so we extracted the body en bloc with the bronchoscope, with a temporary loss of airway control. During this process, the child had a few episodes of desaturation and was revived with reintubation using an endotracheal tube.

A bronchoscopy must be performed once foreign body aspiration is suspected. There has been ongoing controversy associated with the selection between flexible or rigid bronchoscopy. Flexible bronchoscopy is preferred in adults, while rigid bronchoscopy is chosen for paediatric cases because of better control of respiration and safer extraction of the foreign body. It carries a lower risk of foreign body displacement into the distal bronchus compared to flexible bronchoscopy ${ }^{(7)}$. Rigid bronchoscopy was planned for our case after weighing the benefit of controlled oxygenation versus the risk of displacement of the irregularly shaped peanuts upon removal.

The types of forceps selected to extract the foreign body in the paediatric airways is important. Optical forceps (OF) are widely used, but in certain cases, such as impacted and smooth, slippery foreign bodies which are more distally located, they are not a suitable option. In a retrospective study done by Hegde et al., it was demonstrated that DB, Fogarty's catheter (FC) and magnet aided removal as a substitute for OF forceps were successful, allowing ventilation during the extraction, and should therefore be an essential part of the bronchoscopy set ${ }^{(8)}$. In our case, we had difficulty removing the most distally located peanut in the left bronchus using OF. This was mainly due to the narrower and more angular anatomy, and the fact that the peanut was slippery and irregularly shaped, which made it difficult for us to reach and grasp it. The traumatised mucosa and bleeding while grasping made our vision limited. We decided to try using DB, but had to abandon the procedure because of cardiopulmonary complications.

It is important for the surgeon to survey the airways thoroughly after the extraction of the visible foreign body after the first pass. 3-6\% of patients may have bilateral foreign bodies ${ }^{(9)}$. In our case, we noted another peanut over the right main bronchus after removing the first. There were also two pieces over the left main bronchus. We managed to extract the first piece. However, the child had asystole, and cardiopulmonary resuscitation was performed on the operation table upon the removal of the second or final remnant of the peanut. However, his condition deteriorated in the ICU, ultimately resulting in the child's death.

\section{CONCLUSIONS}

Foreign bodies in the tracheobronchial tree are an emergency and pose many diagnostic challenges in the paediatric 
age group. The diagnosis relies on a thorough anamnesis from parents or caretakers, and bronchoscopy is the goldstandard management. A delay in removal may cause high morbidity and mortality. Pre-procedure planning and good communication between the anaesthesiologist and surgeon before and during the operation are vital for the successful outcomes of patients. The proper selection of forceps is important for the successful removal and minimisation of extraction time, as well as allowing ventilation during extraction. Taking a second look into the airway post removal is crucial so as not to miss out on any remnants which can be life-threatening.

\section{Conflict of interest}

The authors do not report any financial or personal connections with other persons or organizations, which might negatively affect the content of this publication and/or claim authorship rights to this publication.

\section{Piśmiennictwo}

1. Toader M, Oprea A, Toader C et al.: Diagnostic techniques for organic foreign body aspiration in children - case reports. Pneumologia 2016; 65: 194-196.

2. Sultan TA, van As AB: Review of tracheobronchial foreign body aspiration in the South African paediatric age group. J Thorac Dis 2016; 8: 3787-3796.

3. Hewlett JC, Rickman OB, Lentz RJ et al.: Foreign body aspiration in adult airways: therapeutic approach. J Thorac Dis 2017; 9: 3398-3409.

4. Cleveland RH: Symmetry of bronchial angles in children. Radiology 1979; 133: 89-93.

5. Sharma SB, Amata AO: Foreign body aspiration in children a report of five cases. West Indian Med J 2010; 59: 717-721.

6. Kendigelen P: The anaesthetic consideration of tracheobronchial foreign body aspiration in children. J Thorac Dis 2016; 8: 3803-3807.

7. Korlacki W, Korecka K, Dzielicki J: Foreign body aspiration in children: diagnostic and therapeutic role of bronchoscopy. Pediatr Surg Int 2011; 27: 833-837.

8. Hegde S, Bahadur U, Kanojia RP et al.: Bronchoscopic airway foreign body extraction without using optical forceps. J Indian Assoc Pediatr Surg 2018; 23: 87-89.

9. Swanson KL. Airway foreign bodies: what's new? Semin Respir Crit Care Med 2004; 25: 405-411. 